\title{
IV. POLEMIKA
}

\author{
ADAM ZIÓŁKOWSKI (Warszawa)
}

\section{Jak o dyktaturze pisać nie należy}

W ostatnim tomie „Czasopisma Prawno-Historycznego" uwagę piszącego te słowa, historyka starożytnego Rzymu, przykuł obszerny artykuł Jana Rudnickiego, Instytucja dyktatury w Republice Rzymskiej (CPH T. LXIII, 2011, s. 11-46). Poniższy tekst jest reakcją na treści w nim zawarte.

W pierwszych dwóch zdaniach artykułu Autor pisze, co następuje: „Celem niniejszego tekstu jest przedstawienie instytucji dyktatury okresu Republiki Rzymskiej (magister populi; dictator), jej źródeł, cech odróżniających ją od pozostałych magistratur wyższych oraz poszczególnych form i celów, dla jakich dyktatorzy byli powoływani. Temat ten nie doczekał się jeszcze w polskiej literaturze szerszego opracowania" (s. 11). Wyjaśnienie tego rodzaju - niestety, bardzo u nas popularne - jest wyjattkowo niefortunne. Nie ma osobnej polskiej literatury naukowej, tak jak nie ma osobnej polskiej nauki: jest jedna na całym świecie nauka, uprawiana przez badaczy różnej narodowości i różnego języka. Nie ma sensu pisać po polsku czegoś, co - jeśli chodzi o treść - zostało już opublikowane w innym języku zrozumiałym dla ogółu naukowej braci: w sytuacji takiej wystarczy bibliograficzny przypis. Otóż w miejscu tym wypada stwierdzić, że w artykule nie ma żadnego samodzielnego wywodu, żadnej oryginalnej myśli: wszystko zostało zaczerpnięte od innych. To oczywiście jeszcze nie kończy sprawy: dobry Forschungsbericht to niezwykle cenna publikacja, nawet jeśli autor nie przemycił w nim nic własnego. Niestety, omawiany artykuł jest pod tym względem niesłychanie ubogi, tak od strony treści, jak i bibliografii, i w żaden sposób nie zasługuje na zaliczenie do kategorii prezentacji historii, a jeszcze mniej - stanu badań. To, co zawiera, to w praktyce wypisy z jednego syntetycznego dzieła (W. Kunkel, R. Wittmann, Staatsordnung und Staatspraxis der Römischen Republik. 2: Die Magistratur, Rechtsgeschichte des Altertums 3.2.2, München 1995, s. 665-719) i jednego króciutkiego artykułu (R.T. Ridley, The Origin of Roman Dictatorship: an Overlooked Opinion, „Rheinisches Museum für Philologie” 122, 1979, s. 303-309). A gdzie 
się podziali tacy klasycy tematu jak G. De Sanctis ${ }^{1}$, R. Werner ${ }^{2}$ czy J. Bleicken ${ }^{3}$ ? I dlaczego S. Mazzarino i H. Soltau są tylko wymienieni z nazwiska, A. Rosenberg i F. De Martino wspomniani z drugiej ręki, a sam Th. Mommsen jest cytowany tylko jeden raz? Powiedzmy jednak, że Autor chciał się oprzeć na najnowszej literaturze; ale oba wyżej wymienione dzieła są też zdecydowanie nienajświeższej daty (rok wydania pierwszego $\mathrm{z}$ nich nie powinien zmylić nikogo: właściwy autor, W. Kunkel, zmarł wszak w 1981 r.).

I jeszcze jedno: by dowieść braku zainteresowania ,literatury polskiej” tematyką dyktatury rzymskiej autor cytuje wyłącznie badaczy prawa rzymskiego: monografie E. Gintowta-Dziewiałtowskiego oraz podręczniki J. Zabłockiego i A. Tarwackiej (Publiczne prawo rzymskie, Warszawa 2005) oraz B. Sitka i P. Krajewskiego (Rzymskie prawo publiczne, Olsztyn 2005). Czyżby nie był świadomy faktu, że dyktatura rzymska jest tematem historycznym, w co najmniej równym stopniu jak romanistycznym? Nie chodzi mi bynajmniej o podkreślanie faktu, że, trzymając się wydawnictw polskojęzycznych, traktują o niej wszystkie nasze syntezy dziejów Rzymu, poczynając od opus magnum Ludwika Piotrowicza (Wielka historia powszechna, III: Dzieje rzymskie, Warszawa 1934)? Gorsze jest to, że ignorowanie literatury historycznej przynosi opłakane skutki: powielanie przestarzałych, dawno odrzuconych konstruktów, a także błędy, zwykłe faktograficzne błędy. Omawiany artykuł jest kopalnią potknięć obu kategorii.

Zacznijmy od sprawy najogólniejszej, a mianowicie - miejsca dyktatury w rzymskim systemie politycznym. Autor, przedstawiając ramy czasowe artykułu - od pierwszej połowy IV w. (cokolwiek miałoby to znaczyć; w zasadzie powinno chodzić mu o leges Liciniae Sextiae z 367 r.) do połowy II w. - precyzuje, że jest to okres „klasycznej Republiki”, „kiedy ustrój republikański był już w pełni ukształtowany, a zarazem nie doszło jeszcze do powstania patologii życia politycznego" i gdy „realizowana była zasada władzy Senatu i Ludu

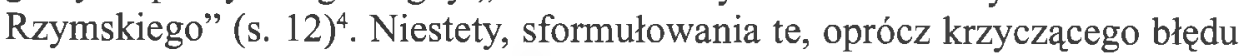
merytorycznego (za republiki władzę miał tylko lud rzymski i ci, którym on ją delegował, czyli magistraci, senat zaś - co najwyżej auctoritas dyskusyjnego zasięgu i mocy; koncepcja senatu jako organu formalnie równorzędnego ludowi wraz z odbijająca to formułą senatus populusque Romanus weszła w użycie

1 G. De Sanctis, Storia dei Romani, Firenze 1957-1964² (zwłaszcza t. 1 i 2).

' R. Werner, Der Beginn der römischen Republik. Historisch-chronologische Untersuchungen über die Anfangszeit der libera res publica, München-Wien 1963.

3 J. Bleicken, Die Verfassung der römischen Republik, Paderborn 1975.

4 W rzeczywistości autor lekceważy własne ramy chronologiczne, sięgając, jak popadnie, do wszystkich ksiąg Liviusa, w których mowa jest o dyktatorach, poprzedzając zasadniczą część artykułu wstępem o genezie urzędu i kończąc go partią o zrealizowanych i planowanych dyktaturach z II i I w. Abstrahując od z gruntu odmiennego statusu hermeneutycznego narracji liwiańskiej w - powiedzmy - drugiej i ósmej księdze (co późniejsze pokolenia mogły wiedzieć o dyktaturach z pierwszej połowy $\mathrm{V}$ w. poza gołym faktem ich zaistnienia?), ma to taki skutek, że $w$ artykule wspomina się na przykład o mianowaniu dyktatorów dla przełamania oporu trybunów plebejskich wobec poboru do wojska (s. 21, 28), które to wydarzenia miały miejsce wyłącznie w V w. 
dopiero za Augusta) są świadectwem nieświadomości ogromnej zmiany, jaka zaszła w ostatnim półwieczu w poglądach na kształtowanie się kompetencji rzymskich instytucji obywatelskich oraz ich formalną i efektywną hierarchię; istotą tej zmiany jest konstatacja, że, jak wszystko pod słońcem, podlegały one nieustannej ewolucji.

W artykule dyktatorzy, choć technicznie mianowani przez konsulów, sa od pierwszego w 504 r. do ostatniego w 202 r. - ,tworami” senatu, który decyduje o ich powołaniu, określa ich funkcje i kontroluje ich poczynania. W rzeczywistości, jak we wszystkich innych sprawach Rzymu republikańskiego, „przewodnia" rola senatu była w tej materii fenomenem późnym, przejściowym i - co najważniejsze - tymczasowym o tyle, że wymagała współdziałania konsula, a nieraz i innych instytucji. To prawda, że pół wieku temu prace historyków były pełne sformułowań podobnych do tych, jakie znajdujemy w artykule - ,dyktator był związany w swoim urzędowaniu wskazówkami Senatu, który określał jego zadania ... a później mógł wpływać na jego decyzje" (s. 15), "Senat zaczął traktować dyktaturę jako magistraturę "dodatkową»" (s. 16), „Senat zasadniczo dawał [dyktatorowi] wolną rękę" [s. 23], „Senat udzielił dyktatorowi wskazówek ... ale de facto pozostawił mu szeroką swobodę działania” [s. 24], „Senat zaczął sięgać po dyktaturę w ... celach” [s. 28] - ale dzisiaj są one tylko świadectwem nieznajomości stanu badań.

Weźmy, na przykład, inicjacyjną rolę senatu w kreowaniu dyktatora. Autor twierdzi, że jego mianowanie miało miejsce ,tylko wówczas, kiedy Senat uprzednio podjął uchwałę stwierdzającą konieczność takiego mianowania i powierzającą to zadanie jednemu z konsulów” (s. 16; por. s. 22: „senat decydował się na mianowanie konsula ..."). Dlaczego więc jeszcze w 339 r. Tib. Aemilius Mamercinus mianował dyktatorem swego kolegę Q. Publiliusa Philona bez pytania kogokolwiek o zdanie (twierdzenie Liviusa [8.12.12], że senat zalecił konsulom tego roku mianowanie dyktatora by pozbawić ich władzy [sic], jest jednym z większych absurdów jego dzieła)? Odpowiedzi dostarcza każde poważniejsze dzieło ostatniego półwiecza poświęcone historii republiki: efektywne kompetencje senatu zaczęły rosnąć po puszczeniu w ruch rzymskiej machiny podbojów (od 327 r.), gdy konsulowie spędzali coraz więcej czasu daleko od Miasta, a jednocześnie, wobec nieustannej jednoczesnej walki na wielu frontach, zaistniała potrzeba instytucjonalnego koordynowania wysiłku militarnego republiki, oraz odkąd uchwalenie lex Ovinia (między 339 a 318 r.), przenoszące ustalanie składu senatu z konsulów na cenzorów i uściślające kryteria wpisywania na jego listę, uczyniło go ciałem o bardzo stabilnym składzie, uniezależniając go w tym kluczowym punkcie od najwyższych magistratów ${ }^{5}$. Do tego czasu senat był nie więcej niż ciałem doradczym konsulów.

${ }^{5}$ Zob. np. K.-J. Hölkeskamp, Die Entstehung der Nobilität, Stuttgart 1987; T.J. Cornell, The Beginnings of Rome. Italy and Rome from the Bronze Age to the Punic Wars (ca. 1000-264 BC), London-New York 1995. 
Otóż wracając do naszego tematu, nie jest przypadkiem, że emancypacja senatu (widoczna wyraźnie poczynając od reakcji konsulów 311 r. na kontrowersyjną lectio senatus cenzorów 312 r.: Diod. Sic. 20.36.5, Liv. 9.30-1-2) zbiegła się w czasie z praktycznym zanikiem dyktatury rei gerundae causa po 310 r. (zaledwie pięć dyktatur po tej dacie, z których tylko dwie pierwsze, z 302 i 287 r., można uznać za sensowne (nagła wojna i konieczność stawienia czoła wyjątkowo ostremu kryzysowi wewnętrznemu; trzy ostatnie niewiele różniły od zabiegów magicznych ${ }^{6}$ ) i radykalnym ograniczeniem dyktatury comitiorum habendorum causa po 306 r. Dyktatura powstała jako najpotężniejszy wyraz $i$ instrument władzy najwyższych magistratów, czyli konsulów, co widać nie tylko po tym, że tylko oni mogli mianować dyktatora, ale i po jedynym ograniczeniu ich swobody w tym zakresie, niestety, niewspomnianym przez Autora: dokonujący dictio konsul mógł mianować każdego, w tym swego kolegę, z wyjątkiem siebie samego. Efektywne ograniczenie władzy konsulów do funkcji jednorocznych wodzów naczelnych (ewentualnie dwuletnich w wypadku prorogacji imperium) oraz ogromny wzrost znaczenia innych instytucji (nie tylko senatu, ale w równej mierze trybunów plebejskich i zgromadzeń ludu/plebsu) obok, a więc kosztem, magistratów, uczyniły dyktaturę przeżytkiem. Widać to najlepiej po fakcie, że nieliczne dyktatury III-wieczne były źródłem ciągłych konfliktów między konsulami (i dyktatorami) z jednej a senatem i (przynajmniej podczas II wojny punickiej, dla której posiadamy obfite i pewne informacje) trybunami plebejskimi z drugiej strony. Nawet gdy zaistniała konieczność zastapienia konsulów w przeprowadzeniu wyboru ich następców, okazało się, że z punktu widzenia funkcjonowania instytucji państwowych lepiej odwołać się do patrycjuszowskich interreges, niż do dyktatora.

By skończyć z wątkiem mianowania dyktatorów: nie wiemy, od kiedy w obyczaju politycznym republiki odpowiednie senatus consultum stało się po temu efektywnym wymogiem, ale sądząc po chronologii podobnych kompetencyjnych ,zdobyczy" senatu - wyznaczania prowincji magistratów, prorogowania imperium, zdobycia kontroli nad aerarium - nastapiło to najwcześniej na początku III w., a więc w czasie, gdy praktycznie zaprzestano mianowania dyktatorów. Dyktatura nie była więc ,,w rękach Senatu uniwersalnym narzędziem radzenia sobie z problemami Republiki" (s. 43); przeciwnie - efektywny wzrost znaczenia izby postępował pari passu $\mathrm{z}$ uwiądem urzędu, właśnie dlatego, że wyjątkowy sposób kreowania i zakres władzy dyktatorów

${ }^{6}$ Wszystkie miały miejsce po wielkich klęskach militarnych - pod Drepanon w 249 r., wycięciu przez Punijczyków jazdy jednej armii konsularnej, zaraz po zniszczeniu drugiej nad Jeziorem Trazymeńskim w $217 \mathrm{r}$. i Kannach w $216 \mathrm{r}$. - w sytuacji, gdy z punktu widzenia militarnego nie było powodu, by kreować dyktatorów (według autora w $217 \mathrm{r}$. bez mianowania dyktatora Rzym byłby pozbawiony wojska [s. 22]; ale w Mieście znajdowali się w tym czasie dwaj pretorzy, z których każdy mógł spokojnie przeprowadzić dilectus). Przyczyna ich mianowania była zupełnie inna: poniesione klęski były dla Rzymian sygnałem, że przeciw sprawowaniu dowództwa przez pokonanych (ale nadal żyjących) konsulów zaprotestowali sami bogowie, którzy wszak z zasady stali po stronie republiki. 
były coraz trudniejsze do pogodzenia z systemem politycznym republiki wykształconym w ostatnim pokoleniu IV i pierwszym III w.

Niezależnie jednak czy jesteśmy w IV, czy w III w., senat nigdy nie mógł niczego nakazać najwyższemu magistratowi, czy to dyktatorowi, czy konsulowi. Nieświadomość tego fundamentalnego faktu nie pozwala autorowi zrozumieć sensu incydentu z 249 r., „kiedy to konsul P. Claudius Pulcher, zapewne niezadowolony z faktu, że musi mianować dyktatora i mu się podporządkować, mianował nim swojego pisarza" (s. 17); nominacja ta była takim samym szyderstwem pod adresem senatu (na zasadzie: ,chcieliście dyktatora, to go macie"; wypada dodać, że M. Claudius Glicia, pisarz, a więc niski apparitor, był synem lub wnukiem wyzwoleńca), jak abdykacja konsulów 223 r., do której wezwał ich senat, gdy seria złowróżebnych znaków podała w wątpliwość prawidłowość ich wyboru: odpowiednio pięć i trzy dni przed końcem ich roku urzędowania. O tym, że pomimo wezwania senatu konsul wcale nie musiał mianować dyktatora, świadczy przypadek M. Valeriusa Laevinusa cos. 210: gdy senat, zasłaniając się prawem religijnym, usiłował ograniczyć jego swobodę wyboru kandydata, konsul obraził się i nie tylko nie mianował dyktatora, ale zabronił obecnym w Mieście pretorom podejmować tę sprawę na wzór sytuacji z 217 r. (o której niżej). To fakt, że do mianowania ostatecznie doszło, ale tylko dlatego, że w sprawę wdali się trybuni plebejscy, całkowicie niezależni od konsulów: dzięki nim udało się puścić w ruch okrężną procedurę, która pozwoliła wezwać do przeprowadzenia dictio - ze wskazaniem osoby przyszłego dyktatora! - drugiego konsula, M. Claudiusa Marcellusa, który nie okazał się solidarny z kolegą i przeprowadził wolę concilium plebis (Liv. 27.5.8-13).

Sformułowania typu: ,dyktator był związany w swoim urzędowaniu wskazówkami Senatu, który określał jego zadania już w uchwale nakazującej mianowanie dyktatora" (s. 23, por. s. 16: „zadanie [dyktatora] określone przez Senat w uchwale nakazującej jego mianowanie"), sa jednak nie tylko gołosłowne - nie znamy wszak żadnej takiej „uchwały” z wyjątkiem zupełnie wyjątkowej „cenzury” M. Fabiusa Buteona w 216 r. - i sprzeczne z tym, co wiemy o funkcjonowaniu instytucji republikańskich w IV i III w. przed Chr., ale przede wszystkim fałszywe z uwagi na optykę i frazeologię. Dyktatura - summum imperium - była jedna; funkcjonalne etykietki: rei gerundae causa, comitiorum habendorum causa, seditionis sedandae causa itp., jakimi opatrują dyktatorów Fasti Capitolini, mają taki sam status jak paralelne zwroty w $A b$ urbe condita, w których nikt nie dopatruje się precyzyjnego oddawania urzędniczej tytulatury. Abstrahując od faktu, że źródła o bardziej prawniczym zacięciu, czy choćby te, które wyliczają urzędy poszczególnych rodzin (Suetonius), nie rozróżniają dyktatorów prowadzących wojnę i wbijających gwóźdź w ścianę Świątyni Kapitolińskiej, i że znamy dyktatorów, którzy działali w kilku „dziedzinach”, konsul przeprowadzający dictio - a także senatorzy i magistrat wzywający ich na sesję, na której postanawiano kreować dyktatora - i tak świetnie wiedzieli, 
do czego ów był im w danym momencie potrzebny. Stąd na przykład dyskusja autora o charakterze przedostatniej klasycznej dyktatury P. Sulpiciusa Glaby w 203 r. (comitiorum habendorum czy rei gerundae causa? s. 29-30) jest chybiona. Warto zresztą zauważyć, że nawet w przypadku dyktatury Sulli istnieja poważne wątpliwości, co do oficjalnego charakteru jej określenia jako legibus scribendis et rei publicae constituendae. Pierwszymi, którzy na pewno się tak formalnie zdefiniowali, byli cezariańcy tresviri rei publicae constituendae w 43 r., również i dlatego, że jako określenie osoby pełniącej funkcje państwowe, termin tresvir miał zupełnie inne konotacje niż dictator.

Przechodzę do spraw bardziej szczegółowych. W artykule o dyktaturze najbardziej uderza powielenie starego błędu o rzekomym wyborze przez lud Q. Fabiusa Maximusa na dyktatora w 217 r. (s. 18; na s. 33 czytamy o, wyborze ludowym" jego magistra equitum), którego to błędu, wbrew zdaniu Autora, Livius bynajmniej nie popełnił; wystarczy skonsultować cały jego przekaz (Liv. 22.8.5-6, 31.8-10), a przede wszystkim artykuł badacza polskiego, choć w języku angielskim, w dodatku wydany w warszawskim wydawnictwie, co najmniej w połowie prawniczym ${ }^{7}$, w którym zagadka dyktatury Cunctatora została definitywnie rozwiązana. Co gorsza, Autor wyraźnie sądzi, że w taki sam sposób dyktatorem został Sulla (s. 37: „wybór Sulli był oczywiście rażąco sprzeczny z prawem. Ewentualne odwołanie się do precedensu w postaci ludowego wyboru Q. Fabiusa Maximusa [...] jest bezzasadne, gdyż wybór Cunctatora był całkowicie wolny, natomiast w 82 roku Miasto było sterroryzowane przez wierne Sulli wojska"), a na dodatek identyfikuje owe rzekome wybory z ustawa, którą Sulla wymusił na zastraszonym interrexie L. Valeriusie Flaccusie i równie zastraszonym zgromadzeniu, dająca interrexowi prawo do mianowania dyktatora (App. BC 1.459-461, zob. Cic. ad Att. 9.15.2): "[Flaccus] rogował lex Valeria de Sulla dictatore [sic], na mocy której zwycięski wódz został ogłoszony dyktatorem". W świetle tych rewelacji zacytowanie - merytorycznie nieposzlakowanej - uwagi Kunkela i Wittmana o bezprecedensowym charakterze mianowania dyktatora przez interrexa dowodzi wyłącznie kompletnego niezrozumienia sprawy. Ale to nie wszystko. Twierdzenie, że ,w obliczu śmierci konsulów Senat powołał na interrexa L. Valeriusa Flaccusa" (s. 37), choć błędne (nie senat powoływał pierwszego interrexa, ale patres, tj. senatorzy patrycjusze; kolejni byli mianowani przez poprzedników), znajdujemy u Appiana, zapewne jako skrót myślowy jego łacińskiego źródła ( $B C$ 1.459); ale skąd Autorowi przyszło do głowy zdanie (s. 37-38), że: „Sulla wymógł mianowanie powolnego sobie L. Valeriusa Flaccusa interrexem (Plut. Sulla 33.1), co było złamaniem reguły losowania kandydatów na to stanowisko (App.

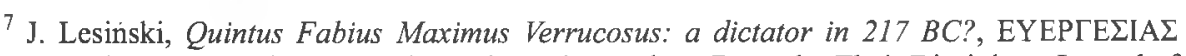
XAPIN. Studies Presented to Ewa Wipszycka and Benedetto Bravo by Their Disciples, „Journal of Juristic Papyrology" Suppl. 1, Warsaw 2002, s. 131-158. 
Civ. 1.458)'"? Plutarch pisze tylko, że Sulla zrobił się dyktatorem, a o takim potworku proceduralnym, jak losowanie kandydatów na interrexa, nie pisze ani Appian, ani żadne inne źródło. Czy Autor przeczytał choć jeden przekaz, na który się powołuje?

Idźmy dalej. Zdanie, że „,konsul mógł przeprowadzić mianowanie [dyktatora] «wstawszy w nocy wśród ciszy (oriens de nocte silentio)» (Liv. 8.23.15)" (s. 16) ${ }^{8}$ świadczy o niezrozumieniu tekstu. Całe zdanie brzmi: cum consul oriens de nocte silentio diceret dictatorem (,skoro konsul, wstawszy, po nocy, w ciszy mianował dyktatora"), i odnosi się do dwóch czynności: auspicjów, odprawianych między północą i świtem (oriens), oraz samej dictio, która wygłosił zaraz po wschodzie (de nocte, nie nocte), przy czym vitium, które miało doprowadzić do abdykacji dyktatora, mogło zdarzyć się podczas obydwu z nich, co jasno wynika z dalszego ciągu przekazu (Liv. 8.23.14-17). Co gorsza, autor ekstrapoluje błędne rozumienie tego epizodu na dictio w ogóle, sugerując, że noc była normalną porą przeprowadzania tej ceremonii, por. s.17: ,jakikolwiek błąd podczas mianowania, a nawet wystapienie niesprzyjających okoliczności (np. przerwanie nocnej ciszy przez jakiś dźwięk) mogło skutkować nieważnością mianowania". Sławne vitium, które doprowadziło do abdykacji Q. Fabiusa Maximusa z pierwszej dyktatury w 221 r. - pisk ryjówki podczas mianowania magistra equitum - też miało jego zdaniem polegać na „zakłóceniu ciszy nocnej” (ibidem), choć ani Valerius Maximus (1.1.5), na którego się powołuje, ani Plutarch (Marc. 5.5), który też wspomina o tym incydencie, nic takiego nie mówią. Wyjątkowo bałamutne jest twierdzenie, że senat decydował się na powołanie dyktatorów comitiorum habendorum causa, ponieważ „okres urzędowania interreges był krótki i często się oni zmieniali, a ich działania mogły być zakłócone zwłaszcza przez ... augurów oraz przez trybunów ludowych, którzy mogli wnieść intercesję przeciwko wyborom przeprowadzonym przez interreges" (s. 29). Po pierwsze: zważywszy, że jedynym zadaniem interregnum było przeprowadzenie wyboru konsulów, pięciodniowe urzędowanie interrexa nie stanowiło żadnej trudności, tym bardziej że jeśli z jakichś przyczyn nie zdołał tego wykonać, mianował następnego, który po pięciu dniach mógł ewentualnie mianować następnego, i tak dalej, aż w końcu któryś dopiął celu. Po drugie: augurzy mogli równie łatwo zgłosić vitium przy wyborach, którym przewodniczył dyktator, co interrex. Po trzecie, veto trybunów plebejskich przeciw komisjom wyborczym (nie tylko kierowanych przez interrexa, ale także magistrata) to stara fikcja annalistyki rzymskiej, z jednej strony anachronicznie przypisującej uznanie przez państwo trybuńskiej intercesji przez

${ }^{8}$ Warto dodać, że omawiany epizod (abdykacja dyktatora M. Claudiusa Marcellusa w 327 r.) jest ewidentną fabrykacja, wzorowaną na historycznej abdykacji jego prawnuka po wyborze na konsula w 215 r. Zob. J. Linderski, The Augural Law, „Aufstieg und Niedergang der Römischen Welt" 2.16.3, Berlin-New York 1986, s. 2146-2312 (2172-2173). 
legendarne leges Valeriae Horatiae z 449 r., z drugiej zaś starającej się zatuszować wstydliwy fakt, że pięcioletnia solitudo magistratuum (375-371, zob. Liv. 6.35.10) była skutkiem walk wewnętrznych, a konkretnie rozbijania siła zgromadzeń wyborczych przez plebejuszy.

Na koniec wymienię kilka błędów rzeczowych, niezwiązanych bezpośrednio z dyktaturą. Twierdzenie, że w wyniku reform C. Mariusa Starszego „armia rzymska przestała być poborową armią obywatelską, a stała się zawodową siłą zbrojną" (s. 37), należy, jak przekonanie o wszechwładzy senatu w wolnej republice, złożyć na karb nieznajomości przez autora stanu badań: choć dawno odrzucone przez naukę , jest ono nadal powtarzane w bardziej staroświeckich opracowaniach. Inne są wynikiem zwyczajnej niewiedzy faktograficznej. $\mathrm{Na}$ stronie 31 czytamy ze zdziwieniem, że „sakralny stan wyjątkowy określany jest w źródłach mianem prodigium", na stronie 35 - o tajemniczych „upoważnieniach od senatu w zupełnie innym kształcie" niż dyktatura, jakie mieli otrzymać wodzowie rzymscy walczacy z Kimbrami i Teutonami, Spartakusem czy sprzymierzeńcami. W wojnie domowej, w której zdobył władzę L. Cornelius Sulla, czyli w latach 83-82, na czele popularów mieli stać C. Marius Młodszy i nieżyjący od 84 r. L. Cornelius Cinna (s. 37). Dwa razy, na stronie 27 i 28, dowiadujemy się, że secesja plebsu z 287 r. była druga z kolei (choć np. Kunkel -Wittmann poprawnie piszą o trzeciej). Na stronie 35 Autor imputuje, że zamordowanie Tiberiusa Semproniusa Graccha i jego zwolenników zostało postanowione przez senat, który ,postawił na eskalację i rozwiązanie siłowe". I na koniec następujący kwiatek. Komentując fakt, że mimo zaprzestania kreowania dyktatorów po 202 r., urząd ten był nadal wymieniany w ustawach, a więc traktowany jako istniejący, Autor dodaje: ,przychodzi na myśl obecność dawno zanikłych urzędów republikańskich, takich jak pretor, konsul czy prokonsul, w sporządzonych jeszcze w VI w. po Chr. justynianskich Digestach" (s. 36). Przed napisaniem tego zdania Autor mógł sprawdzić, kiedy powstały Digesta (533 r.) i kiedy urzędy te zanikły (konsulat jako coroczna magistratura w 541 r., prokonsulat gdzieś w VII w., pretura, funkcjonująca nadal za wczesnych Paleologów, może dopiero w 1453 r.).

Konkluduję. Badania historyków nad instytucjami Rzymu republikańskiego są w pełnym toku. W każdej dekadzie, każdego roku pojawiają się nowe ustalenia. Publikacje, które - jak omawiany artykuł - ignorują owoce tego wysiłku, są nie tylko żałośnie przestarzałe w chwili wydania, ale przede wszystkim szkodliwe, propagując błędne treści i podtrzymując między dyscyplinami bariery, które powinniśmy wspólnie zwalczać, dla wspólnego dobra wszystkich badaczy antyku.

${ }^{9}$ Definitywny cios zadał jej P.A. Brunt, Italian Manpower 225 B.C.-A.D. 14, Oxford 1971. 